\title{
Moet wie administratie zegt ook boekhouding in concernverband zeggen?
}

\author{
Over het bestaan van de groepsadministratieplicht van de holding
}

$$
\text { Mr.drs. J. Verstoep* }
$$

\begin{abstract}
In deze bijdrage beantwoordt de auteur de vraag of een holding op grond van artikel 2:10 BW in haar administratie inzicht dient te bieden in de vermogenspositie van haar dochtervennootschappen. De auteur betoogt dat onvoldoende overtuigende argumenten het bestaan van een zogeheten groepsadministratieplicht rechtvaardigen.
\end{abstract}

\section{Inleiding}

Afgaande op de letter van de wet heeft de administratieplicht van artikel 2:10 van het Burgerlijk Wetboek (BW) enkel betrekking op de individuele rechtspersoon. ${ }^{1}$ Op grond van deze bepaling dient het bestuur ${ }^{2}$ van elke vennootschap zijn eigen administratie te voeren. Talloze vennootschappen maken echter deel uit van een onderneming waarin de holding voor de hele groep administreert en een individualiseerbare administratie op het niveau van de individuele vennootschap ontbreekt. ${ }^{3}$ Daardoor rijst de vraag of de administratieplicht van een holding onder bepaalde omstandigheden niet ook betrekking kan hebben op de administratie van haar dochter-

Mr. drs. J. Verstoep is advocaat bij Wieringa Advocaten te Amsterdam.

1. Art. 2:10 lid $1 \mathrm{BW}$ luidt immers: 'Het bestuur is verplicht van de vermogenstoestand van de rechtspersoon en van alles betreffende de werkzaamheden van de rechtspersoon, naar de eisen die voortvloeien uit deze werkzaamheden, op zodanige wijze een administratie te voeren en de daartoe behorende boeken, bescheiden en andere gegevensdragers op zodanige wijze te bewaren, dat te allen tijde de rechten en verplichtingen van de rechtspersoon kunnen worden gekend.' Deze bepaling heeft betrekking op elke privaatrechtelijke rechtspersoon, maar in dit artikel beperk ik mij tot de voor de naamloze en de besloten vennootschappen met beperkte aansprakelijkheid (hierna gezamenlijk: de vennootschap) uit art. 2:10 BW voortvloeiende administratieplicht.

2. Met H. Beckman, Hoofdlijnen van het jaarrekeningenrecht in Nederland, Deventer: Kluwer 2013, p. 35 ben ik van mening dat de administratieplicht op de rechtspersoon rust en dat het bestuur slechts intern verantwoordelijk is voor naleving daarvan. In HR 24 november 2017, ECLI:NL:HR:2017:3019, NJ 2017/468, r.o. 4.2 wordt expliciet bevestigd dat de administratie van een rechtspersoon aan die rechtspersoon toebehoort en dat de tot de administratie behorende boeken, bescheiden en andere gegevensdragers bij de rechtspersoon dienen te blijven berusten.

3. Voor het gemak neem ik in dit artikel een structuur als uitgangspunt waarbij de holding (indirect) alle aandelen houdt in haar dochtervennootschappen. vennootschappen. Met andere woorden: sluit een op de holding rustende groepsadministratieplicht ${ }^{4}$ niet beter aan bij de economische werkelijkheid waarin concerns als één geheel opereren?

In de literatuur wordt over het antwoord op deze vraag al enige tijd een debat gevoerd. De aanleiding voor dit debat wordt voor een belangrijk deel gevormd door de Landis-uitspraak van de Rechtbank Midden-Nederland van 19 juni 2013. In deze uitspraak werd - net als in een enkele eerdere uitspraak ${ }^{5}$ - geoordeeld dat omdat de administratie van de dochtervennootschappen in kwestie niet op orde was, de holding een schending van de administratieplicht kon worden verweten. ${ }^{6}$

Als ik het goed zie, heeft de Landis-uitspraak verder geen navolging gekregen in de rechtspraak. Wel blijkt uit de toevoeging 'zonder meer' in de volgende overweging van het Soxxarrest, dat bijvoorbeeld ook het Gerechtshof Den Haag twijfelt over het antwoord op de vraag van dit artikel:

'Het hof volgt de curator niet in zijn verwijt dat de administratie van Soxx reeds niet voldoet omdat deze geen inzicht biedt in de vermogenspositie van haar dochteronderneming(-en). Het stellen van een dergelijke eis aan de inhoud van de boekhouding van een moedermaatschappij kan niet (zonder meer) gebaseerd worden op het bepaalde in art. 2:10 BW. Dat laat onverlet dat van het bestuur van een vennootschap die aan het hoofd van een groep van vennootschappen staat en aan die groep leiding geeft, verlangd kan worden dat het voldoende zicht heeft op de financiële gang van zaken bij groepsmaatschappijen; heeft

4. Onder groepsadministratieplicht versta ik in dit artikel een op de holding rustende plicht om in haar administratie inzicht te bieden in de vermogenspositie van haar dochtervennootschappen.

5. Zie de aangehaalde jurisprudentie in noot 20 .

6. Rb. Midden-Nederland 19 juni 2013, ECLI:NL:RBMNE: 2013:CA3225, JOR 2013/237 m.nt. Verboom (Landis), r.o. 8.2.8 en 8.2.9. 


\section{Maandblad}

Ondernemingsrecht

het dat zicht niet, dan kan sprake zijn van kennelijk onbehoorlijke taakvervulling. ${ }^{7}$ (cursivering JV)

Kortom, er bestaat enige controverse of op een holding een groepsadministratieplicht kan rusten. In dit artikel weeg ik de in het debat over de groepsadministratieplicht gevoerde argumenten tegen elkaar af. Voordat ik daaraan toekom, schets ik eerst de achtergrond van de administratieplicht (par. 2). Vervolgens bespreek ik de Landis-uitspraak en de Aino-uitspraak, waaruit tegengestelde opvattingen over het antwoord op de vraag van dit artikel blijken (par. 3). Daarna zet ik de argumenten voor de verschillende opvattingen in de literatuur op een rij (par. 4). Ten slotte bepleit ik dat in zeer beperkte mate verplichtingen van de dochtervennootschappen onder de reikwijdte van de administratieplicht van de holding kunnen vallen, maar dat er onvoldoende grond is om tot het bestaan van een groepsadministratieplicht te concluderen (par. 5).

\section{De administratieplicht}

Op grond van artikel 2:10 BW is het bestuur van een vennootschap verplicht een zodanige administratie te voeren dat de rechten en verplichtingen van de vennootschap te allen tijde kunnen worden gekend. ${ }^{8}$ Volgens de Hoge Raad kunnen deze rechten en verplichtingen worden gekend indien 'men snel inzicht kan krijgen in de debiteuren- en crediteurenpositie op enig moment en deze posities en de stand van de liquiditeiten, gezien de aard en omvang van de onderneming, een redelijk inzicht geven in de vermogenspositie'. ' Ook andere elementen kunnen van belang zijn bij de beantwoording van de vraag of aan de administratieplicht is voldaan. ${ }^{10}$ De eisen waaraan de administratie dient te voldoen, kunnen per vennootschap verschillen en zijn afhankelijk van de aard, opzet, organisatie en werkzaamheden van die vennootschap. ${ }^{11}$

De wetgever ziet het voeren van een deugdelijke administratie als een noodzakelijke voorwaarde voor een doelmatig opera-

7. Hof Den Haag 22 augustus 2017, ECLI:NL:GHDHA:2017:2317, JOR 2017/317 m.nt. Harmsen (Soxx), r.o. 4.9.

8. Tevens bestaat op grond van art. 3:15i BW een met art. 2:10 BW vergelijkbare administratieplicht voor eenieder die een bedrijf of zelfstandig een beroep uitoefent die ik in dit artikel verder onbesproken laat. Het bestuur van een vennootschap dient overigens op grond van de Corporate Governance Code 2016 ook (1) over adequate interne risicobeheersings- en controlesystemen te beschikken, (2) de opzet en de werking van deze systemen te beoordelen en (3) ten aanzien van de effectiviteit van deze opzet en de werking verantwoording af te leggen.

9. HR 11 juni 1993, ECLI:NL:HR:1993:ZC0994, NJ 1993/713 m.nt. Maeijer (Brens q.q./Sarper), r.o. 3.5.

10. HR 10 oktober 2014, ECLI:NL:HR:2014:2932, JOR 2014/327 m.nt. Harmsen (FSM Europe), r.o. 4.9.1. Zie in dit verband E.M. van Hengel, De administratieplicht ex artikel 2:10 BW nader bezien, V\&O 2015, afl. 3, p. 41 .

11. Hof Leeuwarden 3 april 2012, ECLI:NL:GHLEE:2012:BW0725, JONDR 2012/999. Vgl. Hof Arnhem-Leeuwarden 6 december 2016, ECLI:NL:GHARL:2016:9858, JOR 2017/35 m.nt. Harmsen, r.o. 5.9 en Kamerstukken II 1986/87, 21287, 3, p. 10. tioneel en financieel beleid van een onderneming. ${ }^{12}$ Het zorgt ervoor dat het bestuur van een vennootschap tot betrouwbare prognoses en begrotingen en een deugdelijke rekening en verantwoording kan komen. Tevens stelt het voeren van een administratie het bestuur in staat om de jaarrekening op te stellen en om bij tegenvallende resultaten tijdig maatregelen te nemen. ${ }^{13}$ Daarnaast is een beoogd gevolg van de administratieplicht dat zowel bestaande als toekomstige schuldeisers en aandeelhouders van een vennootschap in hun belang worden beschermd, doordat hun inzicht wordt geboden in het reilen en zeilen van deze vennootschap. ${ }^{14} \mathrm{Zij}$ kunnen daar hun beslissingen met betrekking tot een bepaalde vennootschap op baseren. ${ }^{15}$

Schending van de administratieplicht kan grote gevolgen voor $\mathrm{de}\left(\right.$ feitelijk ${ }^{16}$ ) bestuurders sorteren. Als een vennootschap failliet wordt verklaard en haar bestuurders niet hebben voldaan aan de administratieplicht, is namelijk sprake van onbehoorlijke taakvervulling en geldt het wettelijk vermoeden dat deze onbehoorlijke taakvervulling een belangrijke oorzaak is geweest van het faillissement (ex art. 2:138/248 lid $2 \mathrm{BW}$ ). ${ }^{17}$ Bestuurders komen daardoor in de bewijsrechtelijk nadelige positie dat zij dit vermoeden moeten ontzenuwen. ${ }^{18}$ De praktijk leert dat zij daar zelden in slagen, met persoonlijke aansprakelijkheid als gevolg. ${ }^{19}$

In het licht van het bovenstaande is de discussie over een groepsadministratieplicht relevant. Indien de administraties van de dochtervennootschappen onder de reikwijdte van de administratieplicht van de holding zouden vallen (en de bestuurders van de dochtervennootschappen bijvoorbeeld geen verhaal bieden), ontstaan de facto meer mogelijkheden om de bestuurders van de holding een schending van de administratieplicht te verwijten. Het gevolg is vermoedelijk dat eerder tot kennelijk onbehoorlijk bestuur en vervolgens aanspra-

12. Kamerstukken II $1980 / 81,16631,3$, p. 4 : 'het ontbreken van behoorlijke boekhouding en het niet tijdig publiceren van de jaarrekening duidt op een weinig betrouwbaar en serieus ondernemerschap'. Zie tevens Kamerstukken II 1983/84, 16631, 6, p. 19 en 36.

13. Beckman 2013, p. 26-27.

14. Kamerstukken II 1983/84, 16631, 6, p. 21-22.

15. S.M. Bartman, Administratieplicht en Insolventiewet, WPNR 2009/6783, p. 72-76.

16. De administratieplicht kan ook op de feitelijk bestuurder rusten, zoals blijkt uit HR 23 november 2001, ECLI:NL:PHR:2001:AD4508, NJ 2002/95 m.nt. Maeijer (Vlimeta), r.o. 3.6.

17. Tevens kan de bestuurders onbehoorlijk bestuur in de zin van art. 2:9 BW worden verweten en zijn zij strafrechtelijk vervolgbaar op de voet van art. 342 onder 3 en 343 onder 4 Sr. Zie Asser/Maeijer \& Kroeze 2-I* $2015 / 211$ voor een uitgebreider overzicht van de sancties.

18. Vgl. HR 20 oktober 2006, ECLI:NL:HR:2006:AY7916, JOR 2006/288 m.nt. Borrius (Van Schilt).

19. Zie in dit verband Ph.W. Schreurs, De thermometer van het kennelijk onbehoorlijk bestuur. Een onderzoek naar de effectiviteit van art. 2:248/138, lid 1 en 2 BW, TvI 2011/11, waarin na bestudering van 72 uitspraken over dit onderwerp wordt geconcludeerd dat: 'in alle gevallen waar een beroep op 2:10 BW werd gehonoreerd de bestuurder uiteindelijk ook aansprakelijk wordt gehouden voor het tekort', en M.H.C. Sinninghe Damsté \& A. Attaïbi, Een bloemlezing van de recente jurisprudentie over art. 2:138/248 BW, TOP 2017/480. 


\section{Maandblad \\ Ondernemingsrecht}

kelijkheid van de bestuurders van de holding kan worden geconcludeerd.

\section{Twee opvattingen in de rechtspraak}

In de lagere rechtspraak wordt wisselend geoordeeld over het antwoord op de vraag van dit artikel. ${ }^{20}$ Ter illustratie daarvan bespreek ik twee uitspraken die afwijkende opvattingen over de reikwijdte van de administratieplicht laten zien. In de Landis-uitspraak wordt geoordeeld dat de administratieplicht van de holding in kwestie ook betrekking heeft op de verplichtingen van haar dochtervennootschappen, terwijl in de Ainouitspraak juist het tegenovergestelde wordt geoordeeld.

\subsection{Landis-uitspraak: de ruime opvatting}

\section{Feiten}

Landis Group N.V. (hierna: de Landis-holding) vormt met enkele dochtervennootschappen een groep (hierna gezamenlijk: de Landis-groep) die zich aanvankelijk richt op de distributie van ICT-producten in Nederland. $\mathrm{Na}$ haar beursgang in 1998 groeit de Landis-groep in hoog tempo uit tot een complete dienstverlener op de ICT- en telecommarkt in WestEuropa. In twee jaar tijd stijgt het aantal werknemers van 338 tot meer dan 3200. Tevens neemt de Landis-groep in deze periode voor een bedrag van ongeveer EUR 376 miljoen tien concurrerende ondernemingen over, met behulp van een syndicaatslening van EUR 175 miljoen.

Terwijl de Landis-groep explosief groeit, weet zij echter onvoldoende de boekhouding bij te houden en interne controle te voeren. De groep kent achterstanden in de administratie, de debiteurenportefeuille en de intercompany-verplichtingen zijn niet inzichtelijk, transacties en voorraden worden niet goed gedocumenteerd en de administraties van de verschillende dochtervennootschappen sluiten niet aan op het grootboek. Tot overmaat van ramp verloopt ook de implementatie van een nieuw geautomatiseerd administratiesysteem dramatisch.

De problemen van de Landis-groep cumuleren na de zomer van 2001, als de belangrijkste leverancier de distributieovereenkomst opzegt en het afstoten van de distributieactiviteiten mislukt. Als ook het terugbrengen van het personeelsbestand met 500 werknemers niet mag baten en de syndicaatslening van EUR 175 miljoen wordt opgeëist, vraagt de Landis-groep

20. Zie enerzijds Rb. Breda 10 juni 1997, ECLI:NL:RBBRE:1997:AG3105, JOR 1997/95 m.nt. Kortmann (Van Gils I), Hof 's-Hertogenbosch 13 juli 2004, ECLI:NL:GHSHE:2004:AR5637, JOR 2004/292 (Van Gils II), Rb. 's-Hertogenbosch 28 november 2012, C/01/15660/HA ZA 07-609 (n.g.) (Aino I) en Rb. Midden-Nederland 19 juni 2013 , ECLI:NL:RBMNE:2013:CA3225, JOR 2013/237 m.nt. Verboom (Landis), waarin wel het bestaan van een groepsadministratieplicht wordt aangenomen en anderzijds Rb. Gelderland 15 april 2015 , ECLI:NL:RBGEL:2015:2553, JOR 2015/324 m.nt. Harmsen (Gevi), Hof 's-Hertogenbosch 26 mei 2015, ECLI:NL:GHSHE:2015:2008, JOR 2015/227 m.nt. Hekman en Goethals (Aino II) en Hof Den Haag 22 augustus 2017, ECLI:NL:GHDHA:2017:2317, JOR 2017/317 m.nt. Harmsen (Soxx), waarin het tegenovergestelde wordt geconcludeerd. op 23 april 2002 surseance van betaling aan, die niet lang daarna wordt omgezet in een faillissement.

\section{Oordeel rechtbank}

In de procedure waarin de curatoren de bestuurders (en de commissarissen) van de Landis-holding aansprakelijk stellen, laat de Rechtbank Midden-Nederland zich uit over de vraag of op de bestuurders van de Landis-holding een groepsadministratieplicht rust. Voor de beantwoording van die vraag acht de rechtbank onder meer relevant dat (1) de Landis-holding volledige zeggenschap heeft over haar dochtervennootschappen, (2) de groep als doel heeft één economisch samenhangend Europees concern te worden, (3) de Landis-holding rechten verwerft en verplichtingen aangaat voor de hele Landisgroep in het kader van de concernfinanciering en de gezamenlijke inkoop en (4) de resultaten van de Landis-holding in belangrijke mate worden bepaald door die van haar dochtervennootschappen. ${ }^{21}$

Gelet op genoemde omstandigheden overweegt de rechtbank als volgt:

'Bij deze stand van zaken leidt het vereiste van artikel 2:10 lid 1 BW dat de administratie zodanig moet zijn dat men snel inzicht kan verkrijgen in de debiteuren- en crediteurenpositie op enig moment en dat deze posities en de stand van de liquiditeiten, gezien de aard en omvang van de onderneming, een redelijk inzicht geven in de vermogenspositie, tot de slotsom dat het voor Landis Holding, wilde zij als topholding de centrale leiding kunnen uitoefenen, noodzakelijk was dat zij uit haar administratie ook snel een voldoende betrouwbaar inzicht kon verkrijgen in de vermogenspositie van zowel haar Nederlandse als haar buitenlandse dochters. De omstandigheid dat artikel 2:10 BW op die buitenlandse dochters niet van toepassing is, maakt dit oordeel niet anders. De voormelde vraag [of tot de administratieplicht van Landis Holding ook de rechten en plichten van haar dochtervennootschappen horen; JV] moet daarom bevestigend worden beantwoord. ${ }^{22}$

Vervolgens komt de rechtbank tot het oordeel dat de bestuurders van de Landis-holding niet aan de uit artikel 2:10 lid 1 BW voortvloeiende (in casu: groeps)administratieplicht hebben voldaan. De rechtbank concludeert dat de administratie van de Landis-groep in de drie jaar voorafgaand aan het faillissement zulke substantiële gebreken heeft vertoond, dat de rechten en verplichtingen van de Landis-holding en haar dochtervennootschappen niet te allen tijde konden worden gekend. Volgens de rechtbank was het onmogelijk dat iemand op enig moment snel inzicht kon krijgen in de debiteuren, de voorraden en daarmee ook de liquiditeiten.

21. Rb. Midden-Nederland 19 juni 2013, ECLI:NL:RBMNE: 2013:CA3225, JOR 2013/237 m.nt. Verboom (Landis), r.o. 8.2.8.

22. Rb. Midden-Nederland 19 juni 2013, ECLI:NL:RBMNE: 2013:CA3225, JOR 2013/237 m.nt. Verboom (Landis), r.o. 8.2.8 en 8.2.9. 


\section{Maandblad \\ Ondernemingsrecht}

De conclusie van de rechtbank is dan ook dat de bestuurders en commissarissen van de Landis-holding geen redelijk inzicht hadden in de vermogenspositie van de Landis-groep. De belangrijkste oorzaak van dit gebrek aan inzicht lag naar het oordeel van de rechtbank in de voortdurende problemen in de softwaresystemen en het gebrek aan adequate maatregelen om die problemen op te lossen. ${ }^{23}$ Hangende het hoger beroep dat daarna werd ingesteld, is de zaak vervolgens geschikt, waardoor geen hogere rechter zich nog over de Landis-zaak heeft uitgesproken.

\subsection{Aino-uitspraak: de enge opvatting}

\section{Feiten}

Aino N.V. (hierna: de Aino-holding) staat aan het hoofd van een groep vennootschappen (hierna gezamenlijk: de Ainogroep) die eveneens actief zijn in de ICT-sector, voornamelijk op het vlak van advisering, consultancy en detachering. Na een fusie met een andere ICT-onderneming en de overname van een derde ICT-onderneming is de Aino-holding vanaf medio 2000 beursgenoteerd.

De administratie van de Aino-groep is echter niet op orde. Ook deponeert zij haar jaarrekening over het jaar 2000 niet bij het handelsregister. Nadat ook de resultaten van de Ainogroep tegenvallen, failleren in het najaar van 2002 alle vennootschappen die deel uitmaken van de Aino-groep. Vervolgens stelt de curator de bestuurder van de Aino-holding aansprakelijk, waarbij hij onder meer aanvoert dat de bestuurder niet heeft voldaan aan de publicatieplicht van artikel 2:394 BW en dat de administratie van de Aino-holding niet voldoet aan de wettelijke eisen, omdat haar administratie geen voldoende betrouwbaar inzicht geeft in het vermogen en resultaat van haar dochtervennootschappen.

\section{Oordeel rechtbank en hof}

De Rechtbank 's-Hertogenbosch oordeelt in haar tussenvonnis van 28 november 2012 dat de Aino-holding niet heeft voldaan aan haar publicatieplicht en dat sprake is van het (nietweerlegbare) vermoeden dat de bestuurder van de Aino-holding zijn taak onbehoorlijk heeft vervuld. De rechtbank draagt de bestuurder van de Aino-holding daarom op om te bewijzen dat diens onbehoorlijke taakvervulling geen belangrijke oorzaak van het faillissement is geweest. Voorts oordeelt de rechtbank dat de administratie van de Aino-holding inzicht dient te geven in het vermogen en resultaat van haar dochtervennootschappen, maar dat de vraag of aan de administratieplicht is voldaan, gezien de schending van de publicatieplicht, geen bespreking meer behoeft. ${ }^{24}$ De bestuurder van de Aino-holding stelt echter - nadat de rechtbank dat heeft toegestaan tussentijds hoger beroep in.

23. Rb. Midden-Nederland 19 juni 2013, ECLI:NL:RBMNE: 2013:CA3225, JOR 2013/237 m.nt. Verboom (Landis), r.o. 8.7.1.

24. Rb. 's-Hertogenbosch 28 november 2012, C/01/15660/HA ZA 07-609 (n.g.) (Aino I).
Het Gerechtshof 's-Hertogenbosch oordeelt vervolgens in een tussenarrest van 26 mei 2015 dat de rechtbank, met inachtneming van hetgeen het hof in het kader van de andere grieven overweegt, wel degelijk de vraag of aan de administratieplicht is voldaan, dient te beantwoorden. Uit dit arrest klinkt een andere opvatting over (het bestaan van) een groepsadministratieplicht door dan in het tussenvonnis van 28 november 2012 en de besproken Landis-uitspraak. Het hof laat er weinig misverstand over bestaan dat wat hem betreft uit artikel 2:10 BW geen groepsadministratieplicht voortvloeit:

'Anders dan de rechtbank in r.o. 4.1.1 onder b overweegt, brengt het enkele feit dat Aino aan het hoofd stond van een aantal dochtervennootschappen nog niet mee dat de administratie van Aino naast een redelijk inzicht in haar eigen vermogenspositie tevens een voldoende betrouwbaar inzicht in het vermogen en resultaat van haar dochtermaatschappijen zou moeten geven. ${ }^{25}$

De Rechtbank Oost-Brabant ${ }^{26}$ mag zich na voornoemd arrest weer uitspreken over de Aino-zaak. Logischerwijs weet zij zich nu gebonden aan het oordeel van het hof, ${ }^{27}$ met eenzelfde conclusie over de reikwijdte van de administratieplicht als gevolg:

'Aldus moet als uitgangspunt gelden dat de enkele moederdochter verhouding nog niet meebracht dat de administratie van Aino N.V. op enig moment snel een voldoende betrouwbaar inzicht moest geven in ook het vermogen en resultaat van haar dochtermaatschappijen. Dat neemt op zichzelf niet weg dat de administratie van Aino N.V. voldoende inzicht moest geven in haar eigen verplichtingen en dat daaronder ook de verplichtingen vallen die voortvloeien uit de 403-verklaring. ${ }^{28}$

De rechtbank volgt zo het hof in het door hem geformuleerde uitgangspunt dat de Aino-holding niet gehouden is om de administratie van haar dochtervennootschappen inzichtelijk te maken. In de zin daarna oordeelt de rechtbank vervolgens wel dat de verplichtingen die voortvloeien uit de ten behoeve van deze dochtervennootschappen afgegeven 403-verklaring hebben te gelden als eigen verplichtingen en daarom in de administratie van de holding inzichtelijk dienen te zijn. Zonder het hof te bruuskeren concludeert de rechtbank aldus dat op de Aino-holding een soort van groepsadministratieplicht rust ten aanzien van de verplichtingen uit hoofde van de 403verklaring. ${ }^{29}$

25. Hof 's-Hertogenbosch 26 mei 2015, ECLI:NL:GHSHE:2015:2008, JOR 2015/227 m.nt. Hekman en Goethals (Aino II), r.o. 8.6.3.

26. Per 1 januari 2013 is de naam van de Rechtbank 's-Hertogenbosch gewijzigd in de Rechtbank Oost-Brabant.

27. Net als S.M. Bartman, A.F.M. Dorresteijn \& M. Olaerts, Van het concern, Deventer: Wolters Kluwer 2016, p. 83 meen ik enige tegenzin te herkennen in de formulering van de rechtbank.

28. Rb. Oost-Brabant 30 maart 2016, ECLI:NL:RBOBR:2016:1431, JOR 2016/153 (Aino III), r.o. 2.6.3

29. Vgl. Hof's-Hertogenbosch 26 mei 2015, ECLI:NL:GHSHE:2015:2008, JOR 2015/227 m.nt. Hekman en Goethals (Aino II), onder 4. 
Voorts valt het op dat de rechtbank het argument verwerpt dat een groepsadministratieplicht zou bestaan vanwege de financiële verwevenheid tussen de Aino-holding en haar dochtervennootschappen. In de Landis-uitspraak wordt een dergelijke verwevenheid door de rechtbank wel relevant geacht. Voor de Rechtbank Oost-Brabant, die zich aan het oordeel van het hof gebonden weet, vormt dit kennelijk geen relevante omstandigheid (al wordt in de gecursiveerde passage wel aan de mogelijke consequenties van deze verwevenheid gerefereerd):

'Dat een gebrekkige administratie van de dochters uiteindelijk alleszins ook de financiële positie van de moeder kan raken brengt, bezien in het licht van het oordeel van het Hof, nog niet mee dat Aino N.V. haar verplichting uit 2:10 BW niet is nagekomen. ${ }^{30}$ (cursivering JV)

Uiteindelijk oordeelt de rechtbank dat een schending van de administratieplicht noch een kennelijk onbehoorlijke taakvervulling om andere redenen is vast komen te staan. De rechtbank wijst de op artikel 2:138 en 2:9 BW gestoelde vorderingen dan ook af. ${ }^{31}$

\subsection{Afwijkende opvattingen}

$\mathrm{Na}$ bestudering van de Landis- en de Aino-uitspraak is het niet eenvoudig om een eenduidig antwoord te geven op de vraag of de administratieplicht van de holding ook betrekking heeft op de verplichtingen van haar dochtervennootschappen. Uit beide uitspraken - en zelfs uit de daarin geformuleerde overwegingen - spreken afwijkende opvattingen. Het is dan ook niet verwonderlijk dat hierover in de literatuur een debat is ontstaan. In de volgende paragraaf bespreek ik de verschillende argumenten die in dit debat worden gebruikt.

\section{Het debat voortgezet in de literatuur}

Het debat in de literatuur laat zich op heldere wijze samenvatten. Zowel Harmsen als Goethals en Hekman verdedigen het standpunt dat de administratieplicht van de holding ook betrekking kan hebben op de verplichtingen van haar dochtervennootschappen, zoals in de Landis-uitspraak werd geoordeeld. Huizink daarentegen bekritiseert het aannemen van een dergelijke groepsadministratieplicht en is daar fel tegen gekant. Hierna bespreek ik de argumenten van voornoemde auteurs.

\subsection{Argumenten voor de ruime opvatting}

\section{Harmsen: de doelen van de administratie}

In een artikel naar aanleiding van deze uitspraak verdedigt Harmsen dat de rechtbank de vraag of aan de administratieplicht was voldaan breder heeft beoordeeld dan uitsluitend aan de hand van de debiteuren- en crediteurenposities en de

30. Rb. Oost-Brabant 30 maart 2016, ECLI:NL:RBOBR:2016:1431, JOR 2016/153 (Aino III), r.o. 2.6.3.

31. Rb. Oost-Brabant 30 maart 2016, ECLI:NL:RBOBR:2016:1431, JOR 2016/153 (Aino III), r.o. 2.6-2.9. stand van de liquiditeiten van de Landis-holding. Zij spreekt van 'baanbrekende verbeteringen ten opzichte van de jurisprudentie op dit punt tot nu toe', onder meer omdat de rechtbank het doel dat met het voeren van de administratie binnen de Landis-groep werd nagestreefd, betrekt in haar oordeel. Volgens Harmsen is bij de beantwoording van de vraag of aan de administratieplicht is voldaan geen uniforme maatstaf mogelijk, maar is het antwoord daarop afhankelijk van de aard, opzet, organisatie en werkzaamheden van die vennootschap, en dus van de specifieke omstandigheden van het geval.

Harmsen meent dat om te kunnen beoordelen of de administratie in een concreet geval voldoet aan de daaraan te stellen eisen, het van belang is om te weten welk doel met het voeren van een administratie wordt nagestreefd. $\mathrm{Nu}$ de Landis-groep zich ten doel had gesteld één economisch samenhangend Europees concern te worden en vanuit de Landis-holding sprake was van centrale leiding, volledige zeggenschap over de dochtervennootschappen en financiering en centrale inkoop voor het hele concern, is het volgens Harmsen logisch en terecht dat ook de rechten en verplichtingen van de dochtervennootschappen door de rechtbank tot de reikwijdte van de administratieplicht van de Landis-holding werden gerekend. ${ }^{32}$

Ook in haar noot onder het eerder aangehaalde Soxx-arrest verdedigt Harmsen de opvatting dat op het holdingbestuur een groepsadministratieplicht kan rusten. Ter onderbouwing voert Harmsen aan dat het belangrijkste vermogensbestanddeel bij een holding doorgaans het aandelenbelang zal zijn dat de holding heeft in haar dochtervennootschappen. $\mathrm{Nu}$ de holding een administratie moet bijhouden van haar werkzaamheden en deze werkzaamheden in belangrijke mate zullen bestaan uit het leidinggeven aan en beheren van de dochtervennootschappen, zullen de verplichtingen van deze dochtervennootschappen ook onder de administratie van de holding vallen, aldus Harmsen. ${ }^{33}$

\section{Goethals en Hekman: type holding}

Goethals en Hekman verdedigen een vergelijkbaar standpunt als Harmsen. Zij menen dat de aard van een holding van invloed is op de reikwijdte van haar administratieplicht. ${ }^{34} \mathrm{Zij}$ maken daarbij een onderscheid tussen een holding die niet centraal leiding geeft aan haar dochtervennootschappen (hierna: de niet-leidinggevende holding), de holding die dat wel doet (hierna: de leidinggevende holding) en de holding die een verklaring heeft afgegeven waarin zij zich hoofdelijk aansprakelijk stelt voor verplichtingen van haar dochtervennoot-

32. C.M. Harmsen, Vonnis inzake Landis: een stap vooruit op het gebied van de administratieplicht, TvI 2014/27.

33. Noot Harmsen onder Hof Den Haag 22 augustus 2017, ECLI:NL:GHDHA:2017:2317, JOR 2017/317 (Soxx).

34. Deze zienswijze wordt bevestigd in Hof Arnhem-Leeuwarden 6 december 2016, ECLI:NL:GHARL:2016:9858, JOR 2017/35 m.nt. Harmsen, r.o. 5.9, waarin het ging om een betrekkelijk overzichtelijke onderneming', hetgeen van invloed was op de reikwijdte van de administratieplicht. 
schap(pen), conform artikel 2:403 lid 1 onder f BW (hierna: de 403-holding).

De holding van het eerste type - de niet-leidinggevende holding - kent volgens Goethals en Hekman geen groepsadministratieplicht. Omdat de dochtervennootschappen op afstand staan van de holding en volledig zelfstandig opereren, is het aan henzelf om invulling te geven aan hun administratieplicht. $^{35}$

De holding van het tweede type - de leidinggevende holding dient volgens Goethals en Hekman een administratie te hebben die voldoende inzicht biedt in de rechten en verplichtingen van de dochtervennootschappen. $Z$ ij wijzen in dit verband instemmend op de Landis-uitspraak en op het Ogem-arrest, waaruit volgt dat de bestuurstaak van een holding zich mede uitstrekt tot de dochtervennootschappen die deel uitmaken van dezelfde groep. ${ }^{36}$ Tevens benadrukken Goethals en Hekman dat de Hoge Raad in het Sobi/Hurks II-arrest heeft uitgemaakt dat de leidinggevende holding (1) vanaf een bepaalde peildatum aansprakelijk kan zijn jegens crediteuren van de dochtervennootschappen, (2) actief toezicht dient te houden op haar dochtervennootschappen en (3) de feitelijke macht kan hebben om naleving van haar instructies af te dwingen (hetgeen thans is gecodificeerd in art. 2:239 lid $4 \mathrm{BW}) .{ }^{37}$ Dat de leidinggevende holding inzicht dient te bieden in de rechten en verplichtingen van haar dochtervennootschappen betekent overigens volgens Goethals en Hekman niet dat de holding het voeren van de hele administratie dient over te nemen van deze dochtervennootschappen:

'De administratieplicht gaat onzes inziens echter niet zover dat de administratie van de holdingvennootschap als het ware de administraties van de dochtervennootschappen incorporeert. Voldoende is indien middels de administratie van de holdingmaatschappij toegang verkregen kan worden tot de onderliggende benodigde gegevens uit de

35. M.J.F. Goethals \& T. Hekman, De administratieplicht van het bestuur bij holdingmaatschappijen, FIP 2016, afl. 8, p. 28-34.

36. HR 10 januari 1990, ECLI:NL:HR:1990:AC1234, NJ 1990/466 m.nt. Maeijer (Ogem), r.o. 9.1. Zie ook Asser/Maeijer, Van Solinge \& Nieuwe Weme 2 -II* 2009/828.

37. HR 21 december 2001, ECLI:NL:HR:2001:AD4499, JOR 2002/38 m.nt. Bartman en Faber (Sobi/Hurks II). Zie ook M.G. van den Boogerd \& E.J. Luten, De nieuwe flex-bv en doorbraak van aansprakelijkheid in concernverhoudingen, MvV 2013, afl. 3, p. 74. administraties van de betreffende dochtervennootschappen.' 38

Ten aanzien van de groepsadministratieplicht van de holding van het derde type - de 403-holding - overwegen Goethals en Hekman als volgt. In hun noot onder de Aino-uitspraak stellen zij dat de uit rechtshandelingen van de dochtervennootschappen voortvloeiende verplichtingen op grond van de afgegeven 403-verklaring leiden tot eigen verplichtingen van de Aino-holding. $\mathrm{Zij}$ merken op dat als geen inzicht kan worden gekregen in deze verplichtingen, het niet mogelijk is om goed inzicht te hebben in de rechten en verplichtingen van de Ainoholding. Om die reden staat het voor Goethals en Hekman buiten kijf dat in ieder geval op de 403-holding een groepsadministratieplicht rust. ${ }^{39}$

In dit verband wijzen zij ook op het praktische feit dat de dochtervennootschappen van een 403-holding sowieso al informatie over hun vermogenstoestand aan deze holding zullen verschaffen om haar in staat te stellen een geconsolideerde jaarrekening op te maken. Met andere woorden: de facto heeft de 403-holding toch al inzage in de administratie van haar dochtervennootschappen. ${ }^{40}$

\subsection{Argumenten voor de enge opvatting}

Anders dan Harmsen en Goethals en Hekman, bekritiseert Huizink in verschillende bijdragen het aannemen van een groepsadministratieplicht zoals in de Landis-uitspraak. ${ }^{41}$ Allereerst betoogt Huizink dat de administratieplicht slechts betrekking kan hebben op de individuele vennootschap, omdat de wetgever nimmer heeft beoogd om een groepsadministratieplicht in het leven te roepen. Daar voegt hij aan toe dat het aannemen van een dergelijke plicht ook zou indruisen tegen het in Nederland gehanteerde concept van rechtspersoonlijkheid, dat geen ruimte laat voor concernrecht:

'De groep vormt geen juridische entiteit, is geen rechtspersoon en kan dus ook geen eigen rechten of verplichtingen

38. Goethals \& Hekman 2016. Zie in vergelijkbare zin Kortmann in zijn noot onder Rb. Breda 10 juni 1997, ECLI:NL:RBBRE:1997:AG3105, JOR 1997/95 (Van Gils I): 'Ik onderschrijf het oordeel van de rechtbank dat de administratie zodanig moet zijn, dat zowel snel een voldoende betrouwbaar inzicht kan worden verkregen in de positie van de moeder als in die van de dochters. De omvang van de administratieplicht houdt direct verband met de inhoud en omvang van de taak van het bestuur van de moedervennootschap. Hiervoor betoogde ik dat de moedervennootschap gehouden is zorg te dragen voor een zorgvuldige en evenwichtige concernleiding. Wil zij aan deze verplichting kunnen voldoen, dan zal zij snel een voldoende betrouwbaar inzicht moeten kunnen verkrijgen in de vermogenspositie, de liquiditeitspositie en het resultaat van haar respectieve dochters. $\mathrm{Zij}$ zal derhalve ervoor moeten waken dat de administratie van de respectieve dochters deze essentiële management-informatie aan haar biedt.'

39. Noot Hekman en Goethals onder Hof 's-Hertogenbosch 26 mei 2015, ECLI:NL:GHSHE:2015:2008, JOR 2015/227 (Aino II), onder 4.

40. Goethals \& Hekman 2016.

41. J.B. Huizink, De administratieplicht van art. 2:10 BW voor groepsmaatschappijen, TvI 2017/16 en J.B. Huizink, Kennen wij een geconsolideerde administratieplicht?, TvJ 2016, afl. 2, p. 33. Zie eveneens Huizink, in: GS Rechtspersonen, art. 2:248 BW, aant. 18.7. 
hebben. Evenmin als in de geconsolideerde jaarrekening begrippen als geplaatst kapitaal en wettelijke reserves kunnen voorkomen. Dergelijke passiefposten zijn geklonken aan de enkelvoudige jaarrekening, nu de groep opnieuw geen juridische entiteit is en rechtspersoonlijkheid mist. ${ }^{, 42}$

Daarnaast ziet Huizink ook niet de noodzaak van een groepsadministratieplicht. Ook zonder toepassing van artikel 2:138/248 lid 2 BW kan immers tot onbehoorlijk bestuur worden geconcludeerd. ${ }^{43}$ Vanzelfsprekend dient een holding, om een groep te kunnen leiden, inzicht te hebben in de vermogensposities van de verschillende dochtervennootschappen en zorg te dragen voor een systeem waarin daarop betrekking hebbende risico's adequaat worden beheerst en gecontroleerd. Huizink meent echter dat als de holding dat nalaat, dit kwalificeert als onvoldoende concernleiding en om die reden mogelijk ook als onbehoorlijk bestuur, maar niet als een schending van de administratieplicht.

Ook het argument dat op een holding die leidinggeeft aan een groep reeds een concernleidingplicht rust - hetgeen volgens andere auteurs ook een groepsadministratieplicht impliceert -, overtuigt Huizink niet. In zijn ogen kan uit de concernleidingplicht niet worden afgeleid dat de administratieplicht zich mede uitstrekt tot de rechten en verplichtingen van de dochtervennootschappen. ${ }^{44}$ Tegenover het praktische argument dat de informatie over de vermogenstoestand van de dochtervennootschappen in veel gevallen toch al in het bezit van de holding zal zijn, stelt Huizink verder het volgende:

'Hoe wenselijk, zo niet noodzakelijk het ook moge zijn om voor het kunnen opstellen en implementeren van een effectieve en adequate concernstrategie, te kunnen beschikken over daarvoor relevante financiële data van de verschillende groepsmaatschappijen, zowel enkelvoudig als - al dan niet op onderdelen - geconsolideerd, een verplichting tot administratie van dergelijke data volgt niet en kan gelet op de wettekst ook niet volgen uit art. 2:10 lid 1 BW. ${ }^{45}$

Voorts stipt Huizink het demarcatieprobleem aan, dat het op grond van de Landis-uitspraak onduidelijk is of het bestaan van een groepsadministratieplicht ook moet worden aangenomen indien sprake is van een holding die de groep in ietwat

42. Huizink 2017, onder 4

43. Huizink, in: GS Rechtspersonen, art. 2:248 BW, ant. 18.7. Zie ook Huizink 2016.

44. Huizink 2017.

45. Huizink 2017. mindere mate dan een leidinggevende holding centraal aanstuurt. ${ }^{46}$

Over de vraag of de verplichtingen die voortvloeien uit een ten behoeve van dochtervennootschappen afgegeven 403-verklaring in de administratie van de holding inzichtelijk dienen te zijn, laat Huizink zich in de in dit artikel besproken bijdragen overigens niet uit.

\subsection{Bespreking argumenten}

Op het eerste oog spreekt de opvatting vertolkt door zowel Goethals en Hekman als Harmsen aan. Inderdaad zijn concerns economisch gezien tegenwoordig vaak één geheel. Voor een zinnige analyse van de financiële stand van zaken binnen de holding van een concern voegt een uitgesplitst overzicht van de verplichtingen van enkel die holding zelf doorgaans weinig toe - een gedachtegang die ook wel wordt aangeduid als het 'substance over form'-principe. ${ }^{47}$ Daarvoor is de informatie vanuit het hele concern relevanter.

Of deze constatering gevolgen dient te hebben voor de reikwijdte van de administratieplicht is echter de vraag. Voor een economische analyse is een compleet overzicht van de administratie van een groep inderdaad zinvol. Vanuit een juridisch perspectief heeft het echter wel degelijk een meerwaarde om onderscheid te kunnen maken tussen het vermogen van de vennootschappen binnen een groep. De mogelijkheid om vermogen in verschillende vennootschappen te kunnen scheiden, is namelijk een groot goed. Dit impliceert dat, wil een vennootschap zelfstandig kunnen opereren in het rechtsverkeer, zij ook individueel dient te worden gehouden aan de eis om een deugdelijke administratie te voeren.

Het argument van Goethals en Hekman dat het bestuur van een leidinggevende holding in de praktijk vaak al vanuit de hele groep informatie ontvangt om te kunnen begrijpen wat de impact zal zijn van bepaalde beleidsbeslissingen op onder meer de dochtervennootschappen, boet bij nadere beschouwing aan overtuigingskracht in. Het feit dat een holding reeds beschikt over informatie vanuit het concern zou op zichzelf niet zoveel moeten uitmaken. Het zou immers ongewenste gevolgen sorteren als reeds het kunnen beschikken over een administratie daarmee verband houdende verplichtingen zou scheppen. Het enige dat voor de vraag of aan de administratieplicht is voldaan telt, is of de holding voldoende inzage biedt in haar eigen rechten en verplichtingen.

In dat kader ben ik wel met Goethals en Hekman eens dat de administratie van een 403-holding voldoende inzicht dient te

46. Huizink 2017. Huizink verwijst verder niet expliciet naar de in dit artikel besproken publicaties van Goethals en Hekman, maar het ligt in de lijn der verwachting dat hij evenzeer problemen ziet bij het onderscheid dat zij maken tussen de verschillende holdings en de consequenties die dat volgens hen met zich brengt voor de reikwijdte van de administratieplicht van elk van deze holdings.

47. Zie in dit verband bijv. C.J.A. van Geffen, Concernverhoudingen: de geconsolideerde jaarrekening, TvOB 2017, afl. 5, p. 156. 


\section{Maandblad \\ Ondernemingsrecht}

geven in de rechten en verplichtingen die voor deze holding voortvloeien uit de afgegeven 403-verklaring. Dat impliceert dat in ieder geval het voor de holding relevante deel van de administratie van de dochtervennootschappen waaruit deze rechten en verplichtingen blijken, inzichtelijk dient te zijn in de administratie van de holding. De holding is daartoe in mijn ogen reeds op grond van de eigen administratieplicht gehouden. Ik zou dit niet als een groepsadministratieplicht willen bestempelen, in die zin dat als de administraties van haar dochtervennootschappen niet op orde zijn, de holding reeds een schending van haar administratieplicht kan worden verweten.

Bij het inzicht geven in de rechten en verplichtingen die voor de holding voortvloeien uit een 403-verklaring, ligt wat mij betreft echter wel de grens. Harmsen stelt dat de aard, opzet, organisatie en werkzaamheden van een holding dusdanig kunnen zijn dat deze holding inzicht dient te bieden in de rechten en verplichtingen van haar dochtervennootschappen, bijvoorbeeld als de financiële verwevenheid met haar vennootschappen groot is en deze vennootschappen haar belangrijkste vermogensbestanddelen vormen. In deze stelling volg ik haar niet.

Mijn belangrijkste bezwaar is dat ik geen toegevoegde waarde zie in een dergelijke verbreding van de reikwijdte van de administratieplicht. Als elke vennootschap inzicht biedt in haar eigen rechten en verplichtingen, is immers van elke vennootschap de administratie in te zien. In dit verband heeft Huizink ook terecht aangevoerd dat als een leidinggevende holding onvoldoende inzicht heeft in de vermogensposities van haar dochtervennootschappen, sprake kan zijn van onvoldoende concernleiding en mogelijk ook onbehoorlijk bestuur. Op grond daarvan kunnen de bestuurders van deze holding reeds aansprakelijk worden gesteld, zonder dat daar een (vaststelling van een schending van een) groepsadministratieplicht voor nodig is. Dit argument is door geen van de andere auteurs weerlegd.

Wat betreft de toegevoegde waarde van een groepsadministratieplicht is enkel denkbaar dat bestuurders de facto minder eenvoudig aan aansprakelijkheid zouden kunnen ontsnappen doordat de bewijsvermoedens van artikel 2:138/248 lid 2 BW ook betrekking gaan hebben op de administraties van dochtervennootschappen. Dat zou een rechtspolitieke keuze met ingrijpende gevolgen voor bestuurders inhouden, waar in mijn ogen op dit moment geen goede grond voor bestaat. Zoals reeds aangestipt, is het onder het huidige recht immers bewijsrechtelijk al lastig genoeg voor bestuurders om zich tegen een aansprakelijkheidsvordering te verweren, laat staan als gebreken in de administraties van dochtervennootschappen hun in dat kader ook nog zouden kunnen worden tegengeworpen.

\section{Conclusie}

Op grond van het voorgaande ben ik van mening dat, hoewel in toenemende mate sprake is van concerns die economisch gezien als één geheel opereren, onvoldoende overtuigende argumenten het bestaan van een groepsadministratieplicht rechtvaardigen. Wel dient de 403-holding inzicht te bebben in de relevante rechten en verplichtingen van haar dochtervennootschappen, maar slechts in die mate die nodig is om in haar administratie inzicht te bieden in haar eigen (onder meer uit de 403-verklaring voortvloeiende) rechten en verplichtingen. Voor het daadwerkelijk aannemen van een groepsadministratieplicht bestaat geen goede grond. 